\title{
Performance of Sugarcane to Application of Plant Growth Regulators in North Coastal Zone of Andhra Pradesh
}

\author{
V. Gouri ${ }^{1 *}$, N. Rajkumar ${ }^{1}$, M. Bharata Lakshmi ${ }^{2}$, Ch. Mukundarao', \\ K. V. Ramanamurty ${ }^{2}$ and T. Chitkaladevi ${ }^{2}$ \\ ${ }^{1}$ Krishi Vigyana Kendra, Kondempudi, Visakhapatnam, Andhra Pradesh, India \\ ${ }^{2}$ Department of Agronomy, Regional Agricultural Research Station, Anakapalle, ANGRAU, \\ Lam, Guntur, Andhra Pradesh, India \\ *Corresponding author
}

\section{A B S T R A C T}

Keywords

Cane yield, Ethrel, GA3, Germination, Sugarcane, Yield

Article Info

Accepted:

12 December 2020 Available Online: 10 January 2021
A field experiment was conducted at Regional Agricultural Research Station, Anakapalle, Andhra Pradesh during 2015-16 in randomized block design with three replications. Treatments consisting of T1: Conventional planting/farmers practice ( 3 bud setts) T2: Planting of setts after over night soaking in water T3: Planting of sets after over night soaking in $50 \mathrm{ppm}$ ehrel solution T4: Planting of setts after over night soaking in $100 \mathrm{ppm}$ ehrel solution T5: T1+GA3 spray (35 ppm) at 90,120 and 150 DAP T6: T2+GA3 spray (35 ppm) at 90,120 and 150 DAP T7: T3+GA3 spray (35 ppm) at 90,120 and 150 DAP T8: T4 + GA3 spray (35 ppm) at 90, 120 and 150 DAP. The experimental results indicated that planting of sugarcane setts after soaking in $50 \mathrm{ppm}$ or $100 \mathrm{ppm}$ ethrel solution recorded significantly higher per cent germination of $86.6 \%$ and $83.8 \%$ respectively as compared to other treatments. planting of sugarcane three budded setts after soaking in 50 ppm or 100 ppm Ethrel solution and spraying of GA3 (35 ppm) at 90,120 and 150 DAP gave significantly higher cane yield of 92.0 t/ha and 90.6 t/ha respectively. Conventional three budded setts planting recorded significantly lowest cane yield of 80.0 t/ha. Juice quality parameters did not vary significantly due to application of PGRs.

\section{Introduction}

Sustainable sugarcane productivity is the major concern of the sugar industry due to increase in the cost of cultivation and rise in sugar consumption. To step up the sugarcane production research work is focused on the bio dynamics of cane growth and sugar accumulation process. There is a scope of increasing sugar productivity if physiological and biochemical constraints are identified and modified through plant growth regulation (Nickell, 1984). In many canes growing areas initial plant growth (Sprouting and tillering) is restricted by high temperature and low humidity and low temperatures at maturity phase. Poor sprouting and initial growth of ratoon crop also effect the productivity of sugarcane in many areas. Under such conditions growth regulators play an 
important role in enhancing cane and sugar yields. "Plant growth regulators are organic compounds other than nutrients that in small amounts promote, inhibit, or otherwise modify a physiological process in plants (Devlin and Witham, 1986).

In sugarcane many beneficial effects of ethrel have been reported depending up on the time and rate of application. Ethrel found to increase the sprouting of cane pieces in early and late planted conditions, induces tiller development, helps in sprouting of underground stubble buds and can prevent flowering (Yangrui Li and Solaman, 2003). Research results also indicating that application of plant growth regulator GA3 has significantly positive effects on the height, valid stalks and yield of the sugarcane ( $\mathrm{Li}$ et al., 1992; Tan et al., 2007).

Various research programs also revealed that GA3 had an effect on the activity of sucrose phosphosynthase (Iqbal et al, 2011), and promoted the proliferation of sink tissues, leading to an improved assimilation process in sugarcane (Chandra et al, 2015; Verma et $a l, 2019)$. Keeping these facts in view this field study was conducted with the objective to assess the effect of PGRs on sugarcane germination, growth, yield and juice quality.

\section{Materials and Methods}

A field experiment was conducted at Regional Agricultural Research Station, Anakapalle, Andhra Pradesh during 2015-16. Soil of the experimental site was sandy loam. The experiment was laid out in randomized block design with three replications. The test variety was 97A145. Three budded setts were soaked overnight in water (T2 \& T6), 50 ppm ethrel solution (T3 \& T7), 100 ppm ethrel solution (T3 \& T8) and planted in furrows with a spacing of $90 \mathrm{~cm}$. Three budded setts were also planted without any treatment (T1 \& T5).
At 90,120 and 150 days after planting GA3 @ $35 \mathrm{ppm}$ is sprayed in T5, T6, T7 and T8 treatments. Planting was done during the first week of March, 2013. Phosphorus and potassium fertilizers were applied as basal in furrows at the time of planting and nitrogen fertilizer was applied in two equal splits at 45 DAP and 90 DAP. All other agronomic practices like hand weeding, earthing up, trash twist propping etc., were carried out as per recommendation. Growth parameters like germination percent at 20 and 45 DAP, tiller population and plant height at 90 DAP before spraying of GA3 and after spraying at 180 DAP were recorded during crop growth period.

Yield attributing parameters like number of millable canes, cane length were recorded at the time of harvest. Cane yield was recorded after stripping the leaves and detopping. Juice quality parameters viz., sucrose $\%, \mathrm{CCS} \%$ and sugar yield were recorded at harvest by following standard procedures (Meade and Chen 1971). Data collected were statistically analyzed and the results were compared.

\section{Results and Discussion}

\section{Germination}

Germination was recorded at 20 and 45 days after planting and expressed in $\%$ and presented in table- 1. At 20 DAP, significant differences were not observed due to different treatments. However Planting of setts after overnight soaking in $50 \mathrm{ppm}$ ethrel solution recorded highest per cent germination of 80.3 $\%$. At 45 days, planting of setts after soaking in $50 \mathrm{ppm}(86.6 \%)$ or $100 \mathrm{ppm}(83.8 \%)$ ethrel solution recorded significantly higher per cent germination as compared to other treatments. Conventional 3 bud sett planting recorded significantly lowest per cent germination of 76.2 . 


\section{Tiller population}

Number of tillers at 90 days after planting before spraying of GA3 was recorded and data are presented in table -1. Planting of setts after soaking in $100 \mathrm{ppm}(1,56,548 / \mathrm{ha})$ or 50 ppm $(1,54,762 /$ ha $)$ ethrel solution recorded significantly more number of tiller population as compared to other treatments. Planting of setts after over night soaking in water recorded significantly lowest number of tiller population (1,17,261/ha). At 180 days, significant variations are observed in tiller population among different treatments. Planting of setts after overnight soaking in 50 ppm ethrel solution recorded significantly higher number of tillers $(1,46,428 / \mathrm{ha})$ as compared to other treatments followed by planting of setts after soaking in $100 \mathrm{ppm}$ ethrel solution $(1,41,667 / \mathrm{ha})$. Planting of setts after over night soaking in water recorded significantly lower number of tillers/ha $(1,26,190)$.

\section{Plant height (cm)}

Plant height at 90 days after planting was recorded before spraying of GA3 and data was presented in table -1. Plant height did not varied significantly due to different treatments. How ever tallest plants $(145.5 \mathrm{~cm})$ were observed in planting of setts after soaking in ethrel solution and GA3 spray at 90, 120 and 150 days after planting treatments. At 180 DAP significant differences were observed in plant height among different treatments.

Plant height in all GA3 sprayed treatments recorded significantly highest plant height as compared to the other treatments. Spraying of GA3 in conventional three budded sett planting recorded significantly taller plants $(283.4 \mathrm{~cm})$ but found on par with planting of setts after overnight soaking in water (278.2 $\mathrm{cm})$ or $50 \mathrm{ppm}(279.0 \mathrm{~cm})$ or $100 \mathrm{ppm}(273.2$ $\mathrm{cm})$ ethrel solution and spraying of GA3 at 90, 120 and 150 days after planting. Significantly lowest plant height was observed in planting of setts after overnight soaking in water $(254.0 \mathrm{~cm})$.

\section{Length of Millable Cane ( $\mathrm{LMC} \mathrm{cm)}$}

Length of the millable cane was measured at harvest in $\mathrm{cm}$ and data are presented in Table1 . Significantly longest canes were recorded in planting of setts after soaking in $50 \mathrm{ppm}$ $(350.0 \mathrm{~cm})$ or $100 \mathrm{ppm}(345.0 \mathrm{~cm})$ ethrel solution and spraying of GA3 at 90, 120 and 150 days after planting. Conventional 3 bud sett planting recorded significantly lowest length of millable cane $(280.0 \mathrm{~cm})$ at harvest.

\section{Number of millable canes/ha}

Significant differences were observed in number of millable canes due to application of different plant growth regulators (Table-5). Significantly higher number of miillable canes were recorded in planting of setts after overnight soaking in $100 \mathrm{ppm}$ ethrel solution (70,833/ha) and spraying of GA3 at 90,120 and 150 days after planting but found on par with planting of setts after overnight soaking in $50 \mathrm{ppm}$ ethrel solution $(70,486 / \mathrm{ha})$ or water $(68,750 /$ ha) and spraying of GA3 at 90,120 and 150 days after planting. Conventional three budded sett planting recorded significantly lower number of millable canes $(65,972 / \mathrm{ha})$.

\section{Juice quality parameters}

\section{Juice sucrose (\%)}

Cane juices were analysed for sucrose content at harvest (Table-1). Per cent juice sucrose values did not vary significantly due to application of PGRs. However, the per cent juice sucrose values in different treatments varied between 15.94 to 16.76 . 
Table.1 Yield attributes, yield and quality of sugarcane as influenced by different sett treatments during 2015-16

\begin{tabular}{|c|c|c|c|c|c|c|c|c|c|c|c|c|}
\hline Treatment & $\begin{array}{c}\text { Germina } \\
\text { tion }(\%) \\
\text { at } 20 \\
\text { DAP }\end{array}$ & $\begin{array}{c}\text { Germina } \\
\text { tion }(\%) \\
\text { at } 45 \\
\text { DAP }\end{array}$ & $\begin{array}{c}\text { Tiller } \\
\text { populati } \\
\text { on at } 90 \\
\text { DAP }\end{array}$ & $\begin{array}{c}\text { Tiller } \\
\text { populatio } \\
\text { n at } 180 \\
\text { DAP }\end{array}$ & $\begin{array}{c}\text { Plant } \\
\text { height } \\
(\mathrm{cm}) \text { at } 90 \\
\text { DAP }\end{array}$ & $\begin{array}{c}\text { Plant } \\
\text { height } \\
(\mathbf{c m}) \text { at } \\
180 \\
\text { DAP }\end{array}$ & $\begin{array}{l}\text { LMC } \\
(\mathrm{cm})\end{array}$ & $\begin{array}{l}\text { NMC } \\
\text { /ha }\end{array}$ & $\begin{array}{l}\text { Cane } \\
\text { yield } \\
\text { (t/ha) }\end{array}$ & $\begin{array}{c}\text { Juice } \\
\text { Sucrose } \\
\quad(\%)\end{array}$ & $\begin{array}{l}\text { CCS } \\
(\%)\end{array}$ & $\begin{array}{l}\text { Sugar } \\
\text { Yield } \\
\text { (t/ha) }\end{array}$ \\
\hline T1:Conventional 3 bud sett planting & 69.9 & 76.2 & $1,33,929$ & $1,26,190$ & 141.1 & 254.8 & 280.0 & 65,972 & 80.0 & 16.37 & 11.1 & 8.9 \\
\hline $\begin{array}{l}\text { T2:Planting of setts after over night } \\
\text { soaking in water }\end{array}$ & 53.9 & 67.8 & $1,17,261$ & $1,14,286$ & 128.0 & 254.0 & 290.5 & 66,667 & 81.6 & 16.76 & 11.6 & 9.4 \\
\hline $\begin{array}{l}\text { T3:Planting of setts after over night } \\
\text { soaking in } 50 \text { ppm ethrel solution }\end{array}$ & 80.3 & 86.6 & $1,54,762$ & $1,41,667$ & 135.8 & 266.7 & 295.3 & 67,708 & 84.4 & 16.31 & 11.3 & 9.5 \\
\hline $\begin{array}{l}\text { T4-Planting of setts after over night } \\
\text { soaking in } 100 \mathrm{ppm} \text { ethrel } \\
\text { solution }\end{array}$ & 70.8 & 83.8 & $1,56,548$ & $1,41,667$ & 138.6 & 262.2 & 299.0 & 68,055 & 85.1 & 15.66 & 10.7 & 9.1 \\
\hline $\begin{array}{l}\text { T5:T1+GA3 Spray }(35 \mathrm{ppm}) \text { at } \\
90,120 \text { and } 150 \text { DAP }\end{array}$ & 69.0 & 79.6 & $1,48,809$ & $1,34,524$ & 140.6 & 283.8 & 335.0 & 68,402 & 86.1 & 16.28 & 11.2 & 9.6 \\
\hline $\begin{array}{l}\text { T6:T2+GA3 Spray }(35 \mathrm{ppm}) \text { at } \\
90,120 \text { and } 150 \text { DAP }\end{array}$ & 68.3 & 80.1 & $1,37,202$ & $1,38,095$ & 145.5 & 278.2 & 340.0 & 68,750 & 87.5 & 15.94 & 11.0 & 9.6 \\
\hline $\begin{array}{l}\text { T7-:T3+GA3 Spray }(35 \mathrm{ppm}) \text { at } 90,120 \\
\text { and } 150 \text { DAP }\end{array}$ & 73.6 & 81.3 & $1,46,286$ & $1,46,428$ & 143.9 & 279.0 & 350.0 & 70,486 & 90.6 & 16.14 & 10.9 & 9.9 \\
\hline $\begin{array}{l}\text { T8:T4+GA3 Spray }(35 \mathrm{ppm}) \text { at } 90,120 \\
\text { and } 150 \text { DAP }\end{array}$ & 71.5 & 80.6 & $1,38,988$ & $1,41,071$ & 120.5 & 273.2 & 345.0 & 70,833 & 92.0 & 16.56 & 11.3 & 10.4 \\
\hline SEm \pm & - & 1.44 & 2102 & 1381 & - & 4.4 & 12.1 & 731 & 1.2 & - & - & - \\
\hline C.D (0.05) & NS & 4.4 & 6308 & 4191 & NS & 13.4 & 36.7 & 2215 & 3.5 & NS & NS & NS \\
\hline C.V(\%) & 14.5 & 11.1 & 5.6 & 5.8 & 7.2 & 4.85 & 6.64 & 1.85 & 2.34 & 5.8 & 8.0 & 8.5 \\
\hline
\end{tabular}


Table. 2 Yield and quality of sugarcane raised with single node seedlings as influenced by different planting methods and nitrogen levels during 2013-14

\begin{tabular}{|l|c|c|c|c|c|}
\hline \multicolumn{1}{|c|}{ Treatment } & NMC/ha & $\begin{array}{c}\text { Cane } \\
\text { yield } \\
\text { (t/ha) }\end{array}$ & Sucrose \% & CCS\% & $\begin{array}{c}\text { Sugar Yield } \\
\text { (t/ha) }\end{array}$ \\
\hline Methods of planting & \multicolumn{5}{|l|}{} \\
\hline Paired row planting & 57,229 & 85.5 & 15.4 & 11.0 & 9.5 \\
\hline Wider row planting & 48,995 & 76.1 & 14.8 & 10.2 & 7.9 \\
\hline Normal planting & 51,973 & 79.2 & 15.8 & 10.9 & 8.6 \\
\hline SEm \pm & 450 & 0.99 & - & - & \\
\hline C.D(0.05) & 1348 & 3.9 & NS & NS & - \\
\hline N Levels & & & & & \\
\hline N1-112 Kg N/ha (100\% RDN) & 49,193 & 73.4 & 15.1 & 11.2 & 8.2 \\
\hline N2-168 Kg N/ha (150\% RDN) & 51,747 & 80.7 & 15.7 & 11.5 & 9.3 \\
\hline N3-196 Kg N/ha (175\% RDN) & 57,257 & 86.9 & 15.4 & 11.5 & 10.0 \\
\hline SEm \pm & 450 & 0.9 & - & - & \\
\hline C.D (0.05) & 1348 & 2.8 & NS & NS & - \\
\hline Interaction C.D(0.05) & NS & NS & NS & NS & - \\
\hline
\end{tabular}

\section{Commercial cane sugar $(\%)$}

Commercial cane sugar was calculated treatment wise and presented in table1.CCS\% did not vary significantly due to different treatments.

\section{Cane yield (t/ha)}

Cane yield was recorded at harvest and presented in Table -1 . Significantly highest cane yield (92.0 t/ha) was recorded in planting of setts after overnight soaking in $100 \mathrm{ppm}$ ethrel solution and spraying of GA3 at 90,120 and 150 days after planting but found on par with planting of setts after overnight soaking in $50 \mathrm{ppm}$ ethrel solution and spraying of GA3 at 90,120 and 150 days after planting (90.6 t/ha). Conventional 3 budded sett planting recorded lowest cane yield of 80.0 t/ha. Similar observations are also made by Praharaj et al (2018) in U.P.

\section{Sugar yield}

Sugar yield was computed treatment wise. Sugar yield did not varied significantly due to different treatments but highest sugar yield (10.6 t/ha) was recorded with T8 treatment i.e planting of setts after overnight soaking in $100 \mathrm{ppm}$ ethrel solution and spraying of GA3 at 90,120 and 150 days after planting.

In conclusion the studies on use of plant growth regulators (PGRs) for enhanced yield and quality of sugarcane conducted at Regional Agricultural Research Station, Anakapalle during 2015-16 season revealed that overnight soaking of sugarcane setts in 100 ppm ethrel solution followed by spraying of GA3 at 90,120 and 150 days 
after planting enhance the germination, tiller population and there by cane yield ( $92 \mathrm{t} / \mathrm{ha}$ ) as compared to the conventional 3 budded sett planting (80.0 t/ha.).

\section{Funding}

Authors are thankful to the Acharya N.G Ranga Agriculture University Lam, Guntur for providing the fund.

\section{Conflict of Interests}

The authors have declared no conflict of interests exist

\section{Acknowledgement}

Authors are highly acknowledged the support given by staff of RARS, Anakapalle

\section{References}

Chandra, A.; Verma, P.K.; Islam, M.N.; Grisham, M.P.; Jain, R.; Sharma, A.; Roopendra, K.; Singh, K.; Singh, P.; Verma, I. 2015 Expression analysis of genes associated with sucrose accumulation in sugarcane (Saccharum spp.hybrids) varieties differing in content and time of peak sucrose storage. Plant Biol. 17, 608-617.

Develin, R.M. and Witham, F.H. (1986). Commercial uses of Gibberellins. In plant physiology, fourth edition. CBS publishers and Distributors. PP 4082.

Develin, R.M. and Witham, F.H. (1986). Commercial uses of Gibberellins. In plant physiology, fourth edition. CBS publishers and Distributors. PP 408

Develin, R.M. and Witham, F.H. 1986 Commercial uses of Gibberellins In plant physiology fourth edition. CBS publishers and distributors PP:408

Iqbal, N.; Nazar, R.; Khan, M.I.R.; Masood, A.; Khan, N.A.2011 Role of gibberellins in regulation of source-sink relations under optimal and limiting environmental conditions. Curr. Sci. (Bangalore) , 100, 998-1007.

Develin, R.M. and Witham, F.H. (1986). Commercial uses of Gibberellins. In plant physiology, fourth edition. CBS publishers and Distributors. PP 408

Develin, R.M. and Witham, F.H. (1986). Commercial uses of Gibberellins. In plant physiology, fourth edition. CBS publishers and Distributors. PP 408

Li, Y.R., Lin, Y.K., Yang, L.T., Ye, Y.P., Pan, H., Chen, Z.C., Wei, Z.T \& Qin, B.Q. (1992). Effects of sucrose-cane promote on yield and sucrose content in sugarcane. Journal of Guangxi Agricultural University.11(3):31-36.

Meade G P and Chen J C P. 1971 sugarcane hand book $10^{\text {th }}$ edition John wiley and sons. New Yark.

Nickell, L.G. (1984). A review of plant growth regulators in the sugar cane industry. Sugar y Azucar, pp. 17-20.

Praharaj S, Singh D, Guru S.K, Meena B R 2017. Effect of plant growth regulators on tiller dynamics and yield of sugarcane. International Journal of bioreso75-78

Tan, X.P., Li, N.M., Zhou, Y.M., Zhang, J., Wang, Y., \& Chen, Z. 2007. The effects of different concentration

Develin, R.M. and Witham, F.H. (1986). Commercial uses of Gibberellins. In plant physiology, fourth edition. CBS publishers and Distributors. PP 408 of gibberellin on the quality and yield of garden cane. Journal of Suagar and Canesugar, 4,8-13,27.

Verma, I.; Roopendra, K.; Sharma, A.; Chandra, A.; Kamal, A. 2019 Expression analysis of genes associated with sucrose accumulation and its effect on source-sink relationship in high sucrose accumulating early maturing sugarcane variety. Physiol. Mol. Biol. Plants 25, 207-220.

Yangrui Li and S.Soloman.2003. Ethephon- A versatile growth regulator for sugar industry. Sugar Tech. Vol.4 (5) : 213223. 


\section{How to cite this article:}

Gouri, V., N. Rajkumar, M. Bharata Lakshmi, Ch. Mukundarao, K. V. Ramanamurty and Chitkaladevi, T. 2021. Performance of Sugarcane to Application of Plant Growth Regulators in North Coastal Zone of Andhra Pradesh. Int.J.Curr.Microbiol.App.Sci. 10(01): 1581-1587.

doi: https://doi.org/10.20546/ijcmas.2021.1001.184 